\title{
Judas, the disciple who was known to the high priest: A deconstruction of the betrayal based on John 18:15
}

\author{
Author: \\ Patrick Chatelion Counet ${ }^{1,2}$ \\ Affiliations: \\ ${ }^{1}$ Department of Religious \\ Studies, University \\ of Amsterdam, The \\ Netherlands \\ ${ }^{2}$ Faculty of Theology, \\ University of Pretoria, \\ South Africa \\ Note: \\ Prof. Dr Patrick Chatelion \\ Counet is participating \\ as research associate \\ in the research project \\ 'Biblical Theology and \\ Hermeneutics', directed \\ by Prof. Dr Andries G. van \\ Aarde, honorary professor \\ in the Faculty of Theology \\ of the University of \\ Pretoria, South Africa.
}

Correspondence to:

Patrick Chatelion Counet

email:

p.j.e.chatelioncounet@

gmail.com

\section{Postal address:}

Javastraat 120, $6524 \mathrm{ML}$,

Nijmegen, The Netherlands

Dates:

Received: 27 Sept. 2010

Accepted: 09 Oct. 2010

Published: 07 June 2011

How to cite this article: Chatelion Counet, P., 2011, 'Judas, the disciple who was known to the high priest: A deconstruction of the betrayal based on John 18:15', HTS Teologiese Studies/Theological Studies 67(1), Art. \#923, 7 pages. DOI: $10.4102 /$ hts.v67i1.923

(C) 2011. The Authors. Licensee: OpenJournals Publishing. This work is licensed under the Creative Commons Attribution License.
After his arrest, Jesus is taken to the high priest. According to John 18:15 he is accompanied by 'another disciple'. In this article, I discuss the possibility that this other disciple was Judas. He is the one who was known to the high priest. The arguments to put him in this position are derived from a narrative analysis of the Gospel. What is the actantial role of Judas in the Gospel? Tradition describes him as an opponent of Jesus. Against this, one can see him as a helper who supports Jesus' intention to convince the high priest and the Sanhedrin of his divine mission. In the group of Jesus Judas carries the purse. The text of the Gospel uses a curious Greek word (almost a hapax legoumenon), glôssokomon, for 'purse'. In the Septuagint, this word indicates the Ark of the Covenant. It is highly significant for the role of Judas. It shows that the text of the Gospel sometimes generates meanings that the author cannot control.

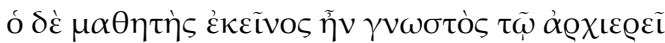

\section{Introduction}

I am pleased to contribute an article to this liber amicorum (I hope Andries van Aarde sees me as an amicus - due to the distance between South Africa and the Netherlands our meetings have been few and far between), in particular because this contribution will be on the dissolution of betrayal. It would perhaps be better not to equal deconstruction with dissolution, as it is, in fact, a process of rebuilding: nothing is destroyed, but by taking the building blocks apart, a new building is created. We can let John be John and still obtain a different view of Judas. ${ }^{1}$

\section{Deconstruction}

Deconstruction uses the component parts and elements of a text ${ }^{2}$, identifying new connections or relating them to similar texts, construing new meanings in the process. Deconstruction is close reading, aimed at the intentio operis and the uncontrollable strength of words and meanings.

To achieve their aims, authors deploy notions and meanings that often possess earlier layers of meaning which they may not be able to control. As a result, the intentio auctoris can be in conflict with the intentio operis ${ }^{3}$, that is, that the text may contain meanings that the author wanted to avoid, but which he cannot contain or control.

Regarding Judas, the intention of the author of the fourth gospel is unambiguous: he introduces Judas in chapter 6 verse 71 at the end of a conversation between Jesus and the twelve disciples. When Peter, on behalf of the twelve disciples, confesses his faith ('We believe and know that you are the Holy One of God'), Jesus tells him: 'One of you is a devil (diabolos)' (Jn 6:70). The evangelist informs the readers that Jesus refers to Judas: 'He was speaking of Judas, son of Simon Iscariot, for he, though one of the twelve, was going to betray (paradidonai) him' (Jn 6:71). Each time Judas appears in the narrative, he is denoted by the epithet 'traitor' (Jn 12:4; 13:2; 18:2). To make a saint out of this sinner can only be called deconstruction if the gospel itself provides the building blocks.

\section{The view of William Klassen}

In his book Judas: Betrayer or Friend of Jesus? William Klassen puts forward a convincing argument for the rehabilitation of Judas.

\section{This article is a rewriting of a chapter from Over God zwijgen. Postmodern Bijbellezen, (1998).}

2.Derrida uses the term deconstruction for the first time in his work De la Grammatologie (1967); for a philosophical introduction on the idea of deconstruction see Jonathan Culler, On Deconstruction: Theory and Criticism after Structuralism (1982): my thesis 'John, a postmodern gospel. Introduction to Deconstructive Exegesis Applied to the Fourth Gospel' (2000) provides an introduction for biblical exegesis.

3.See Umberto Eco, The limits of interpretation, (1990), pp. 44-63. 
The first and main exculpatory argument lies in the meaning of the word paradidomi. Klassen has found that there is not a single example in ancient Greek in which this word means 'betray' and even pejorative connotations like 'deceit' and 'disloyalty' are absent. He takes the view that lexica stating the meaning 'betray' are guilty of theologisation of the concept through the gospels (Klassen 1996:47-58). In the Septuagint, the word paradidomi is used to translate some twenty different terms from the Hebrew Bible, but 'betray' is not amongst them. To indicate notions like 'mislead', 'betray' or 'deceive' the Septuagint uses the word paralogizomai. Flavius Josephus uses paradidômi 293 times, but not a single time in the meaning of 'betray'. Its neutral meaning is 'hand over', which at times even has a positive connotation ('lay one's hands on by lucky coincidence').

Klassen concludes that Judas' action was originally, before the gospels were put down in writing, indicated by the neutral word 'handing over'. Later, when Judas' deed met with increased condemnation, the word became ever more negatively charged, so much so that it eventually acquired the connotation 'betray' in the gospel. Klassen holds the view that Judas' act in itself did not signify betrayal, but that the subsequent interpretations (of the evangelists) turned it into betrayal.

The interpretation 'betrayal' is itself a form of betrayal, namely of someone who carried out the will of Jesus (Klassen 1996:62-74). Judas cooperated with Jesus with the purpose of establishing contact between Him and the Jewish Temple authorities. Jesus did not intend to have himself killed, but to draw the attention of the highest authorities to his message he had to deliver himself into the hands of those charged with carrying out the divine will: the religious authorities. However, these authorities showed no interest whatsoever in Jesus' mission. Judas' main task was therefore, as Klassen states in line with Schleiermacher, to shake the Temple authorities out of their indifference and incite them to action. Judas started to play the role of $m^{e}$ sira. ${ }^{4}$ He set himself up as an informer of the scribes and the Sanhedrin, or Jesus chose him as part of a plan He devised. The Hebrew word masor, translated in the Septuagint by paradidômi (!), means 'to inform'. Information is given ('passed on') about a person. What is inside is handed over to the outside world: this may relate to possessions or to information, but also, on a voluntary basis, to the person himself, who wishes to defend himself or elucidate his position. This puts Jesus' exhortation to Judas in John 13:27: 'Do quickly what you are going to $\mathrm{do}^{\prime}$, in a different light. It denotes cooperation between two persons: 'I know whom I have chosen ...' (Jn 13:18). Why it was Judas who was chosen remains unclear, but no more than if it had been X or Y. The relevant disciple had to have contacts at the highest level. Did Judas have such contacts? Klassen does not pronounce on this, but I would suggest appealing to John 18:15:

Simon Peter and another disciple followed Jesus. Since that disciple was known to the high priest, he went with Jesus into

4.See also J. Duncan Derrett, 'The Iscariot, $\mathrm{M}^{\mathrm{e}}$ sira, and the Redemption', in Journal for the Study of the New Testament, 2 (1980) 2-23; against Derrett who thinks that in the beginning Judas was an informer of Jesus, who afterwards became a counterspy, Klassen sticks to the positive role of Judas until the end. the courtyard of the high priest, but Peter was standing outside at the gate.

In this article, I will present two additions to Klassen's view, one concerning the identification of Judas as the disciple who was known to the high priest and the other a more detailed elaboration of Klassen's assumption that Jesus wished to establish contact with the highest authorities. This assumption must be substantiated as the gospels suggest that, by contrast, Jesus rather tried to avoid the authorities. It should be demonstrated that Jesus very much wanted to meet the authorities, not to have himself killed, but to convince them of God's plans. To achieve this, He needed the help of a friend who knew these authorities.

\section{Judas, the disciple who was known to the high priest}

An anonymous figure occurs in John 18:15: 'Simon Peter and another disciple followed Jesus. Since that disciple was known to the high priest ...' (Jn 18:15). It makes sense that exegetes have wondered who the other disciple was. Traditionally, he is identified as the disciple 'whom Jesus loved' (Jn 20:2). ${ }^{5}$

One of the reasons to think that the disciple concerned is the one whom Jesus loved is the article 'the' as seen in 'the other disciple' with reference to John 20:2, in which the beloved disciple is called 'the other disciple'. However, if 'the other disciple' is to be considered yet another name for 'the beloved disciple', the definite article 'the' [ho] should have been used, otherwise the person concerned remains undefined. Nevertheless, most ancient Greek manuscripts read 'another' disciple [allos] in John 18:15, rather than 'the other' [ho allos]. The oldest manuscripts, Papyrus ${ }^{6}$ and the Codex Sinaïticus, also read 'an' other disciple, without a definite article. In the Codex Sinaïticus, a corrector has gone so far as to add the definite article ho to the original text, which only stated allos, 'another' disciple. This cannot be the beloved disciple.

Judas is a candidate because he was present at the time of Jesus' arrest, even playing a main part in it and because it is very well possible that as an informer of the high priest he has access to the palace of the high priest and now wishes to argue Jesus' case together with Him. The reason why the evangelist did not state that this person was Judas - when according to his sources and information it actually was Judas - is obvious: from the evangelist's point of view Judas is a thief who betrayed his master for money (Jn 12:6). How can such a person show any interest in the further proceedings now that he has bagged his reward? His information that the other disciple, the one known to the high priest, is Judas must therefore be wrong, the evangelist reasons. Describing him as the beloved disciple would do too much violence to the truth. The same applies to other possible candidates like Joseph of Arimathea or Nicodemus, whose names, like all other names, John could easily have revealed. The reason why he keeps silent about the identity of the disciple who was known to the high priest is that he does not know what to do with the

5.See for instance Martin Hengel, The Johannine Question, (1990), p. 79, who demonstrates that this identification dates back to the church fathers. 
fact that this man is, according to the tradition, Judas. In that situation, just remaining neutral and stating that this is another disciple who remains unidentified, would seem the best solution.

The Talmud mentions a striking example of an apostate rabbi who, after his apostacy, is consistently referred to as 'the other'. The rabbi in question is Elisha ben Abuyah, a tannaite scribe, contemporary of rabbi Akiba and teacher of rabbi Meir. When he converts to a form of gnostic dualism, he is instantly and exclusively referred to by the name Acher, 'the other' ${ }^{6}$ By analogy, it may well be that the evangelist, once Judas has committed his betrayal, refuses to call him by his name any longer.

Or did he really not know who the man in 18:15 was? It would seem rather unlikely that there is someone amongst Jesus' disciples who is known to the high priest and was in the lion's den with Jesus in his final hours, but whose identity is unknown in the tradition. The evangelist is withholding valuable information, which may conceal Judas' role as informer, that is, as mediator between Jesus and the Temple authorities.

\section{Judas and Simon Peter}

The literature on the fourth gospel states that John often presents his dramatis personae in pairs. ${ }^{7}$ Andrew and Philip appear as a couple during the feeding of the five thousand (Jn 6:5-8) and during Jesus' meeting with the Greeks (12:22). Nicodemus and Joseph of Arimathea act together at Jesus' burial (19:38-42). The sisters Martha and Mary form such a couple as well (11,1vv and 12:2-3). Van Tilborg adds to these the special couples Philip and Nathanael (1:45-46), the two sons of Zebedee (21:2) and in a sense also Thomas, because he, though alone, is always called Didymus, the Twin (11:16; 20:24 and 21:2). Yet the most significant couple is generally felt $^{8}$ to be Simon Peter and the beloved disciple. The Gospel of John would reflect a dispute between the Great Church (Simon Peter) and the Johannine circle (the beloved disciple). ${ }^{9}$

The fact everyone is overlooking is that Simon Peter also forms a couple with Judas. They are the only ones called by name when Jesus discusses the meaning of his flesh and blood with his disciples (Jn 6:60-71). At the Last Supper, Simon Peter takes the initiative that eventually causes Jesus to reveal the name of 'the traitor' (13:24-26). When Judas has left in the night and Simon Peter virtually immediately afterwards starts speaking, he too is related to night and betrayal (13:38). At Jesus' arrest, Simon Peter and Judas are again the only ones called by name (18:5-11). The scene immediately

6.See the Encyclopedia Judaica (New York 1971), vol. 6, 668-670, in grateful acknowledgement of Sjef van Tilborg who brought this possible analogy to my attention.

7.See Sjef van Tilborg, Imaginative Love in John, (1993), pp. 166-167.

8.See amongst others Hengel, The Johannine Question, pp. 76-80 and Raymond E. Brown, The Gospel according to John (XIII-XXI), (1966), p. 1120vv.

9.See Raymond E. Brown, The Community of the Beloved Disciple, (1979), pp. 82-84; $161 \mathrm{vv}$.

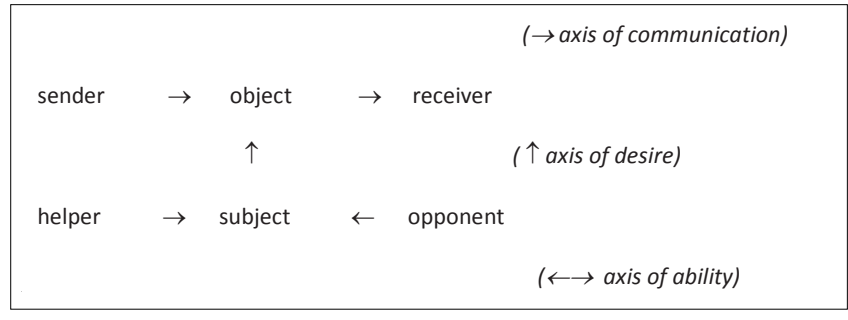

FIGURE 1: Actantial narrative schema.

following the arrest tells us that Simon Peter and 'another disciple' followed Jesus (18:15). This is the disciple who was known to the high priest.

From the point of view of these pairings, there are two disciples who could have been Simon Peter's partner at the palace of the high priest, Judas and the beloved disciple. Yet as the beloved disciple is indicated as 'the' other disciple elsewhere (20:2), which may have been a ground for the corrector of the Codex Sinaiiticus to change the text of 18:15 and add the particle ho to allos, we must conclude that Judas is Simon Peter's partner in 18:15. He is the one who is known to the high priest. He is also a more logical candidate than the beloved disciple who (as tradition has $i^{10}$ ) is still a youth.

If we accept Klassen's hypothesis of the informer, we also know how and why Judas knows the high priest.

\section{Helpers and opponents}

In terms of semiotics, in particular the actantial model of A.J. Greimas, Judas has the role of adjuvant or helper. ${ }^{11}$

The classic or traditional explanation of St. John's Gospel, based mainly on the explicit views of the narrator, is outlined in the actantial narrative schema as follows; the sender is God, the sent one is Jesus. From John 3:16-17 this is a recurrent theme in the gospel. The object that is being communicated (or must be communicated) is the self-revelation of Jesus (see, apart from the many ego eimi or I am-pronouncements, Jn $1: 5 ; 1: 31 ; 2: 11 ; 3: 19 ; 6: 40 ; 11: 25-26 ; 14: 21 ; 17: 2-3 ; 21: 1)$. The receivers are the faithful $(3: 16-18 ; 17: 20)$ or those entrusted to Jesus (6:39-40; 17:2-3). There are not many real helpers in St. John's Gospel; by contrast, there are many opponents.

Culpepper evaluates the dramatis personae on the basis of their response to Jesus' offer, whether they accept it in faith or not (1983:146-148). Thus, the Jews are denoted as opponents, as are Jesus' brothers. Neither opponents nor helpers are those who accept Jesus' offer (his teachings), but do not go so far as openly following him. Examples of these are Joseph of Arimathea, Nicodemus and perhaps Pilate. Culpepper recognises real helpers and paradigmatic disciples in Peter as a shepherd and martyr, in Jesus' mother and in the beloved disciple. The last response to Jesus' offer is the disciples turning back (Jn 6:66) and the desertion of Judas. In Culpepper's opinion, Judas is Jesus' main antagonist.

10.Hengel, The Johannine Question, p. 133.

11.See Greimas and Courtés, Semiotics and Language: An Analytical Dictionary, (1982). 


\begin{tabular}{|c|c|c|c|c|}
\hline God/Father & $\rightarrow$ & (self)revelation & $\rightarrow$ & $\begin{array}{c}\text { faithful } \\
\text { the cosmos }\end{array}$ \\
\hline $\begin{array}{l}\text { Jesus' mother } \\
\text { Simon Peter } \\
\text { beloved disciple } \\
\text { (helpers) }\end{array}$ & $\rightarrow$ & Jesus & $\leftarrow$ & $\begin{array}{l}\text { Judas } \\
\text { the Jews } \\
\text { (opponents) }\end{array}$ \\
\hline
\end{tabular}

FIGURE 2: Actantial narrative schema of St. John's Gospel - traditional explanation (Culpepper).

Culpepper is slightly too quick in viewing Peter as a helper, as in doing so he passes over Peter's denial which is forgiven and forgotten in the final chapter (Jn 21:15-19). Peter's discipleship cannot simply be called paradigmatic and neither can Judas' role simply be branded despicable.

To summarise St. John's Gospel in terms of semiotics, the narrative concerns the transformation of the absence of an object to its presence. The object is knowledge on the person of Jesus - revelation of this knowledge. The absence of knowledge on the person of Jesus - that he has been sent from God with a divine mission - has to be transformed in knowledge of his identity and origin. The dynamic subject that effects this transformation is Jesus, which He does by means of self-revelation, installed (sent) for this purpose by the destinator Father, God. The beneficiaries or destinates are the faithful and those who have been entrusted to Jesus. A summary of this main programme can be found in John 14:21, where Jesus says: '[To those who love me] I will reveal myself'. Figure 2 gives a schematic outline of this narrative programme.

In this classical model, Simon Peter and Judas are each other's opposites as helper and opponent. The actantial role of Judas as an opponent has become paradigmatic to such an extent that Kermode views Judas as a dramatis persona who becomes obsessed with his own narrative role: 'Betrayal becomes Judas'. ${ }^{12}$

\section{Jesus' contact with the Jewish leaders}

Several help programmes are required to effect the transformation of the main programme. For instance, in the manipulation phase the destinator has to install the dynamic subject. In St. John's Gospel this is effected by the incarnation of the Word (Jn 1:14) and God sending His Son (Jn 3:16-17). In the competence phase, the dynamic subject has to qualify as the person capable of effecting the transformation. In the case of Jesus, this help programme consists of convincing people of his mission. Only then, in the performance phase, the main change, namely self-revelation, can take place. For this purpose, the dynamic subject, Jesus, has to stand the ultimate or main test.

What does this main test, or, as the gospel calls it, the content of the cup Jesus has to drink from (Jn 18:11) consist of? Is it

12.Fr. Kermode, The Genesis of Secrecy. On the Interpretation of Narrative, (1979), pp. $84-85$. his death on the cross and his resurrection? Or is it a debate with the Temple authorities and the high priest - not without danger to himself?

The first answer, death on a cross and resurrection, would suggest that Jesus is seeking death. It is what the narrator of the gospel wants us to believe: that Jesus is aware of the inevitability of his suffering and that this suffering is linked to death. Yet the question is whether it really is Jesus who is seeking death or whether this is merely John's theological view? Could it be that the evangelist, knowing about Jesus' death on the cross and the reports about His suffering and resurrection, fills in Jesus' philosophy of life, as well as His life, with exactly these elements?

Perhaps Jesus did not seek death but a meeting, a (highly dangerous) religious summit, the outcome of which he did not know - and did not want - to lead to his death. We know that Jesus actually had several contacts amongst the Jewish leaders. The Pharisee Nicodemus is said to be 'a leader of the Jews (Jn 3:1) and Joseph of Arimathea, a disciple of Jesus (Jn 19:38), is, as reported in Mark 15:43, a respected member of the Sanhedrin. We do not know whether the initiative for these contacts may actually have come from Jesus, for John's narrative perspective is too much determined by the eventual enmity between Jesus and the authorities. However, the fact that Jesus, compared to the accounts in the synoptic gospels, visits Jerusalem so often (Jn 2:13; 5:1; 7:10vv; 12:12-19), may be an indication that he tried to make contact with the Temple authorities. In particular during the Feast of Tabernacles (Jn 7-9), Jesus actually seems to be the one who is seeking contact by addressing 'the Jews', the 'authorities', in particular, albeit at this stage the temple guards rather than the high priests (7:45). Jesus has not yet succeeded in breaking through to the highest echelons.

I would like to suggest another possible help programme. By meeting the high priest and convincing him of his teachings, identity and authority Jesus intends to try to get as much acceptance as possible for his teachings and self-revelation. The high priest is the instance of least distance to God and most authority with the people. Jesus may have thought that it might be better to convince one person for the whole people instead of having all the people perish.

The main test of the gospel, then, the test on which the main transformation (Jesus' revelation to the world) depends, consists of how Jesus will come through the confrontation with the Temple authorities and the high priest. We know that failing this test (execution) will be the preamble to glorious success (resurrection). We also know that the evangelist considers the success (the resurrection and the life) a predestined event (Jn 11:25-26). To John, the main test consists of the question, which in fact is no question at all to him, whether Jesus will conquer death. In line with this, the evangelist assumes that the way of dying (execution by death on a cross) has also been predestined (Jn 3:14 and 12:32), thus creating the almost unacceptable image of a masochistic Christ who desires suffering and a violent death. 
Every biographer of Jesus knows that the gospels have been written too late to retrieve Jesus' real motives. Nevertheless, we are inclined to believe what the evangelists claim, accepting as a fact that Jesus, the son of a carpenter from Nazareth, preferred to avoid the scribes, Pharisees and high priests (anxiously but also slightly arrogantly), instead of trying to establish contacts amongst them. Research into the Sitz im Leben of the gospels (the material and spiritual situation they were written in and which they addressed) has shown that this was exactly the situation the early Christians found themselves in: they avoided the Jewish authorities because these authorities, who were after their lives and threw them out of the synagogues, persecuted them. ${ }^{13}$

The question is how to arouse the high priest's and religious authorities' interest in Jesus. To answer this question, a help programme needs to be deployed which requires an informer who turns 'Jesus' (i.e. his message of God) over to the authorities. This informer has to bring the teachings of Jesus, his claims and his successes with a growing body of followers to their attention. This means that within the actantial narrative schema Judas is not a traitor or opponent, but rather an adjuvant or helper. In the next section, I will compare his role as an informer and mediator between Jesus and the authorities to that of Simon Peter.

\section{Simon Peter versus Judas}

As stated earlier, in the fourth gospel Simon Peter and Judas form a couple. Their roles can be compared as follows.

When Judas is introduced, Simon Peter has just made a confession that comprises the core of the gospel: 'You have the words of eternal life. We have come to believe and know that you are the Holy One of God' (Jn 6:68-69). Jesus counters the confession the Holy One of God by the shattering announcement that amongst them is a devil (Jn 6:70). He does not say and nowhere else is it stated that this is Judas. On the contrary, the scene has strong links to Simon Peter's confession in the synoptists, where he states: 'You are the Messiah' (Mt 16:16). Initially, Jesus confirms this confession (Mt 16:17), but in the next passage he calls Simon Peter Satan (Mt 16:23). In John, the confession and revelation of the presence of a devil have been put together in one scene. It is not inconceivable that Jesus refers to Simon Peter when he uses the word diabolos.

The next scene in which both Judas and Simon Peter play a part is that of the Last Supper, preceded by the washing of feet. It is generally assumed that the quote from Psalm 41:9, 'The one who ate my bread has lifted his heel against me', refers to Judas.

In Psalm 41, David speaks about enemies who wish him dead (Ps 41:5). The word hypocrisy is used. The Septuagint reads

13.For the Gospel of John on this subject see J. Louis Martyn, History and Theology in the Fourth Gospel, (1979), pub. 24-63; he postulates the excomm Theology in the fourth Gospel, (1979), pp. 24-63, he postulates the excommunication

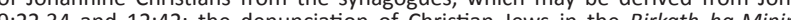
$9: 22.34$ and 12:42; the denunciation of Christian Jews in the Birkath ha-Minim from the Jewish Eighteen Prayer would be part of this process; see also Brown, The Community of the Beloved Disciple, p. 66 en $71 \mathrm{vv}$. matên, speaking 'untrue' or 'false' words about someone. Next, David complains of people whispering together about him (Ps 41:7). Both the hypocrisy and the secret whispering characterise the person of Simon Peter in St. John's Gospel. In John 13:24, he does not address straight to Jesus but signed to the beloved disciple in order to take him apart. John 18:17 and 18:25-27 relate his denial of Jesus. In addition, everybody present at the Last Supper ate bread and everybody lifted their heel during the washing of the feet (with Peter playing a leading part). It is therefore not impossible to read the quote from Psalm 41:9 (in view of the context from which the quote was taken and the context in which it is placed) as an early allusion to Peter's denial of Jesus.

When Judas leaves in the night to carry out what Jesus ordered him to do, Simon Peter turns the spotlight on himself again. He declares that he will follow Jesus wherever he goes, followed by the rather theatrical exclamation 'I will lay down my life for you' (Jn 13:37). Jesus responds with a sneer: 'Before the cock crows, you will have denied me three times' (13:38).

Considering that Judas, by contrast, actually does risk his life by trying to force an audience with the high priest for Jesus and that he, if he is the other disciple mentioned in John 18:15, actually follows Jesus where he goes, namely all the way into the high priest's interview room, the contrast with Simon Peter is significant.

On the Mount of Olives, Simon Peter and Judas are facing each other again. Judas is carrying out Jesus' orders by bringing him into contact with the high priest's slave (the evangelist tells us the name of this slave; how likely is it that he knows the name of this slave but not the name of the disciple known to the high priest?). Simon Peter threatens to make a complete mess of the whole matter by cutting off the right ear of this Malchus (Jn 18:10). By doing so he reveals himself yet again as an opponent. Who knows: this may well be the real cause for the enmity between the authorities and the group of Jesus.

A last point of comparison between Judas and Simon Peter can be found in John 18:15vv, if we assume, as argued earlier, that Judas was the disciple known to the high priest. Judas arranges for Peter to enter the courtyard of the high priest as well. At that point, they go their separate ways, with Peter revealing himself as a traitor: 'You are not also one of this man's disciples, are you?'. He said, 'I am not' (18:17). The evangelist leaves him behind at the coal fire somewhere in the courtyard (18:18) and focuses on the interrogation scene of Jesus and the high priest.

Where did he leave the other disciple (i.e. Judas)? Certainly not at the coal fire. In my view, it is not improbable that he accompanied Jesus into the high priest's rooms, as he is the former's disciple and the latter's acquaintance. The fact that this is known in the palace becomes apparent in the question asked by the woman at the gate, who asks Peter: 'You are not also (mê kai su) one of this man's disciples, are you? ...'. It shows that it is known in the palace that the other, the one 


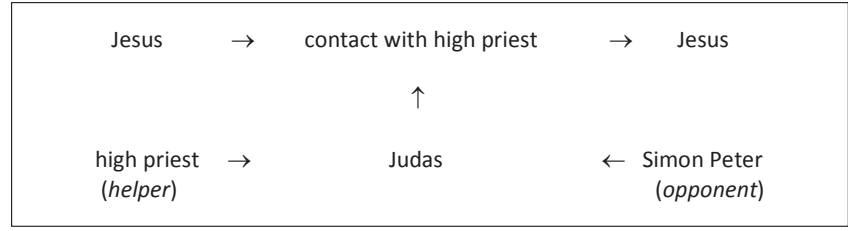

FIGURE 3: Actantial narrative schema of a help programme in the competence phase of St. John's Gospel.

\begin{tabular}{|c|c|c|c|c|}
\hline God & $\rightarrow$ & $\begin{array}{c}\text { (self) revelation } \\
\uparrow\end{array}$ & $\rightarrow$ & people \\
\hline $\begin{array}{l}\text { Judas } \\
\text { (helper) }\end{array}$ & $\rightarrow$ & Jesus & $\leftarrow$ & $\begin{array}{c}\text { Peter } \\
\text { (opponent) }\end{array}$ \\
\hline
\end{tabular}

FIGURE 4: Actantial narrative schema of the main programme (performance phase) after the rehabilitation of Judas.

known to the high priest, was a disciple in any case. Clearly, he never tried to hide this. Given the fact that this disciple established the contact, it is not inconceivable that he will also argue Jesus' case with Jesus.

Moreover, whilst Jesus and Judas are questioned together, a hypocrite - in that sense, the real traitor - is standing outside listening to a cock crowing.

\section{Help programme (contact) and main programme (Revelation)}

If we apply the help programme (establishing contact between Jesus and the high priest) following the terms of the actantial narrative schema, it shows that Jesus is both sender (he installs the dynamic subject) and receiver. Judas is the dynamic subject, Simon Peter an opponent. The high priest, in so far as he grants Judas' request, is a helper (see Figure 3).

Compared to the classic narrative schema (Figure 2), Figure 3 results in just a minor change to the main programme of St. John's Gospel: Judas and Simon Peter change places (Figure 4).

\section{Deconstruction of the eucharist}

Until now, perhaps sufficient arguments have been given for the rehabilitation of Judas, but we will go one step further. I will argue that Judas is the first one who, according to John, consumed the (eucharistic) flesh of Jesus, thus becoming the first to receive eternal life.

The institution of the eucharist seems to be missing in St. John's Gospel, although the eucharist is given a special place in the three synoptic gospels, namely at the Last Supper (Mt 26:26-30 and parallel texts).

Whereas in the synoptists the bread represents the bread of reconciliation and the sign of the new Covenant, in John (also in the context of the Last Supper) the bread is the means to point out the traitor (Jn 13:26) and whereas the synoptists view the broken bread as a metaphorical sign of Jesus' death, in the passage in John the bread literally leads to death because Judas takes it with him (Jn 13:30). In the context of the Last Supper, the synoptic eucharist takes the character of a Passover meal, that is, with offertory and thanksgiving, but in St. John's gospel the words about his flesh and blood are placed in a context of strife, with the people listening to Jesus' words without understanding them (6:30) and the Jews complaining about him (6:41). Many disciples condemn his words as unacceptable (6:60) and leave him in their droves. (6:66). Do we see, as Bultmann postulates, a eucharistic editor at work here ${ }^{14}$ In my view, flesh and blood are rather the signs of an absolute low, a prefiguration of death. Whereas the synoptists renew the Covenant with God in the eucharistic meal, the Johannine flesh and bread of Jesus point to an irreversible and unrepeatable end that, through Judas, brings Satan in the picture as well, when the narrator or author says, 'After he [Judas] received the piece of bread, Satan entered into him' (13:27).

\section{Author versus text}

Let us return to the question asked at the start of this article. John depicts Judas as an instrument of Satan (Jn 6:70:71; 13:2 and 13:27). Would it be possible to find an undercurrent of meanings in the text, an intentio operis that contradicts this intentio auctoris? In other words, would it be possible to use the text against its author? In that case, the same text would, unchanged and deconstructively, no longer be the same. Unchanged but no longer the same: we can let the text be the way it is (let John be John) yet understand its elements in such a manner that they free Judas from the devil.

The text allows us to do so because a number of terms used in John 6, which speaks about bread and flesh, are identical to those used in John 13, in which the Last Supper is described:

- $\quad$ artos, bread (passim; 13,18)

- trôgô, eat, chew, masticate $(6,54 ; 13,18)$

- eklegomai, choose $(6,70 ; 13,18)$

- $\quad$ pempô, send $(6,38.39 ; 13,16.20)$

- $\quad$ paradidômi, hand over $(6,64.71 ; 13,21)$

- diabolos, devil $(6,70 ; 13,2)$.

Each of these words refers to Judas, yet with a significant difference: in John 13, these words have negative connotations, whereas in John 6 the connotations are positive. The 'chosen' in 13:18 is also the one who ate my bread [and] has lifted his heel against me'. In John 6, the same words sound very different: 'Those who eat my flesh ... have eternal life'. Can it be that this refers to Judas?

The eucharist is not mentioned in John, but there is one person who receives bread from Jesus at the Last Supper. Psômion in John 13:30 is usually translated as 'piece of bread', because readers think of John 13:18 (and of the bread of the synoptic Last Supper), but it may as well be a 'piece of meat'. ${ }^{15}$ By contrast, to the synoptists, Jesus does not have a

14.Rudolf Bultmann, Das Evangelium des Johannes, (1941), p. 174vv.

15.Psômion is the diminutive of psômos, literally meaning a 'bite', a piece torn or bitten off something. It can refer to either a piece of bread or a piece of meat. Liddell \& Scott have a reference to Homer's Odyssey (9.374) in which the Cyclops regurgitates pieces of human flesh [psômoi d'andromeoi]. 
Passover meal in the fourth gospel; otherwise one could say that he gave Judas a piece of the Passover lamb as a symbol of the Lamb of God. Anyway, John 13:26 can be read to say that Judas is given the flesh of Jesus himself. If Judas eats it (Jn 13:30 explicitly states that he received it) he will, in accordance with John 6:54, have eternal life.

So does he eat it? The text does not go into detail about this. It may be that he put it into the sleeve of his robe or into his bag or purse. As it happens, this purse may be the last missing link in the Johannine narrative about the supper. The synoptists present the bread and the wine as a renewal of the Covenant, but John does not seem to address this topic. Yet where the author keeps silent, the text may still speak. The term used to refer to Judas' purse or money-bag is an (almost) hapax legoumenon, namely glôssokomon (Jn 12:6 and 13:29). On behalf of the twelve disciples, Judas holds the glôssokomon. This term has a long history. Bauer's Wörterbuch zum Neuen Testament gives various meanings for glôssokomon, including 'purse' or 'coffer', but also the more general 'case' or 'holder', an object to keep things in, a 'chest' or 'casket'. The first part of the word comes from glôssa, tongue or language, the second part from komeô, to carry or hold. Literally, the term means 'carrier of the tongue' or 'mouth'. In 2 Samuel 6:11, the term glôssokomon has a special meaning: 'The Ark of the Lord (glôssokomon Kuriou) remained in the house of Obededom the Guttite for three months' (Septuagint version of the Codex Vaticanus). Glôssokomon is used here as a synonym for kibôtos, the Ark of the Covenant.

Thus, the Covenant is not missing in the Last Supper in the fourth gospel - it only rests covertly in the hands of Judas: he carries the Ark. If he keeps the meat or bread (sign of the Covenant) offered to him by Jesus in the glôssokomon, the (renewed) Covenant has again arrived where it belongs, in the Ark.

This explanation will most likely not correspond to the author's intentions, but this is exactly what I intended to demonstrate in the preceding: that a text is stronger than its author and generates levels of meaning that are beyond the author's control. The author of St. John's Gospel has the full intention to depict Judas as a traitor and the information that the 'other' disciple in John 18:15 was Judas does not suit this intention. If the author had this information, he chose to conceal it, but the words of the text itself enable us to rehabilitate Judas and recognise him not as a traitor, but as a confidant of Jesus who, together with Jesus, argues the gospel before the judgement seat of the high priest. The intentio operis of St. John's Gospel seems stronger than the intentio auctoris. Author and text go their different ways. Depending on whether we listen to the author or his text, Judas is a traitor or a confidant, a murderer or the man who prepares the way of eternal life, child of the devil or friend of Jesus, carrier of the bread of death or carrier of the Ark of the Covenant.

\section{References}

Bultmann, R., 1941, Das Evangelium des Johannes, Vandenhoeck \& Ruprecht, Göttingen.

Brown, R.E., 1966, The Gospel according to John (XIII-XXI): Introduction, translation and notes, The Anchor Bible Doubleday, New York.

Brown, R.E., 1979, The Community of the Beloved Disciple: The Life, Loves and Hates of an Individual Church in New Testament Times, Paulist Press, New York.

Culler, J.D., 1989, On Deconstruction: Theory and Criticism after Structuralism, Routledge, London.

Chatelion Counet, P.J.E., 1998, Over God zwijgen: Postmodern Bijbellezen, Meinema, Zoetermeer.

Chatelion Counet, P.J.E., 2000, John, a postmodern gospel: Introduction to Deconstructive Exegesis Applied to the Fourth Gospel, Brill, Leiden.

Culpepper, R.A., 1983, Anatomy of the Fourth Gospel: A Study in Literary Design Fortress Press, Philadelphia.

Derrett, J.D., 1980, 'The Iscariot, M'sira, and the Redemption', Journal for the Study of the New Testament 2, 2-23. doi: 10.1177/0142064X8000200801

Derrida, J., 1967, De la grammatologie [Of grammatology], Les Éditions de Minuit, Paris.

Derrida, J., 1972, La dissemination, [Disseminatione], Éditions du Seuil, Paris. Eco, U., 1990, The limits of interpretation, Indiana University Press, Bloomington.

Greimas, A.J. \& Courtés, J., 1982, Semiotics and Language: An Analytical Dictionary, Indiana University Press, Bloomington.

Hengel, M., 1990, The Johannine Question, SCM and Trinity Press, London.

Klassen, W., 1996, Judas: Betrayer or Friend of Jesus?, Augsburg Fortress, Minneapolis.

Kermode, F., 1979, The Genesis of Secrecy: On the Interpretation of Narrative, Harvard University Press, Cambridge, MA

Martyn, J.L., 1979, History and Theology in the Fourth Gospel, Abingdon, Nashville.

Van Tilborg, S., 1993, Imaginative Love in John, E.J. Brill, Leiden. 